\title{
PENINGKATAN ORGANIZATIONAL CITIZENSHIP BEHAVIOR DAN SPIRITUAL QUOTIENT MELALUI PELATIHAN BERBASIS NILAI SPIRITUAL GURU MTs
}

\author{
Maisah \\ Fakultas Tarbiyah IAIN Jambi \\ email:maisahjambi@gmail.com
}

\begin{abstract}
Abstrak: Penelitian bertujuan untuk mengetahui peningkatan OCB dan SQ guru di MTs melalui pelatihan berbasis nilai-nilai spiritual serta korelasi antara OCB dan SQ guru. Penelitian menggunakan metode kuasi eksperimen. Pelatihan yang melibatkan 58 guru di MTs dilaksanakan selama tiga hari dengan materi pelatihan terkait dengan character building, kerja, dan produktivitas dalam Islam. Data diambil melalui tes, yakni sebelum dan sesudah pelatihan dengan sebuah instrumen yang berupa soal-soal pilihan ganda. Pada akhir penelitian ditemukan bahwa OCB dan SQ responden masing-masing meningkat sebesar $52,13 \%$ dan $53,56 \%$ yaitu dalam kategori "sedang". Sementara korelasi antara OCB dan SQ diperoleh menunjukkan adanya korelasi positif yang signifikan. Dengan demikian, pelatihan berbasis nilai spiritual yang bekelanjutan diperlukan untuk menjaga "stamina" OCB dan guru SQ sehingga kualitas dan produktivitas pekerjaan guru meningkat.
\end{abstract}

Kata kunci: organizational citizenship behavior, spiritual quotient, nilai spiritual

Abstract: The objectives of the research are toreveal the increase of teachers' OCB and SQ at Madrasah Tsnawiyah (MTs) through spiritual values-based training and to delineate the correlation between teachers'sOCB and SQ. The approach used in this study is a quasi-experimental quantitative method. The training involved 58 teachers at the MTs held for three days with training materials related to character building, employment and productivity in Islam. Data were retrieved through before and after training tests in the form of multiple choice questions. The results indicate that the teachers' OCB and SQ respectively increase by $52.13 \%$ and $53.56 \%$, which can be categorized as "medium". OCB and SQ indicates a positive correlation. Thus the spiritual value-based training needs to be made sustainable in order to maintain the "stamina" of teachers'OCB and SQ so as to improve teachers' quality and productivity.

Keywords: organizational citizenship behavior, spiritual quotient, nilai spiritual

\section{LATAR BELAKANG}

Pendidikan merupakan cara yang paling tepat bagi manusia untuk menjaga alam sekitar dan kaitannya dengan kehidupan manusia itu sendiri. Untuk menjamin suatu pendidikan yang berkualitas, sekolah sebagai lembagahendaknya memiliki suatu sistem yang handal.Dengan sistem tersebut,sekolah mampu menciptakan generasi yang handal pula. Oleh karena itu, sistem suatu sekolah harus dapat memastikan bahwa setiap siswa masuk pada sekolah tersebut memperoleh pendidikan yang dapat menjamin berkembangkan berbagai macam bentuk keterampilan. Misalnya, keterampilan berpikir kritis dan kreatif, keterampilan berkomunikasi, keterampilan bekerjasama dengan orang lain, mampu memahami nilai-nilai moral spiritual serta mengimplemantasikannya dalam kehidupan seharai-haris. Hal ini sesuai dengan tujuan pendidikan yakni untuk menciptakan manusia yang bertaqwa kepada Tuhan yang Mahas Esa dan berbudi pekerti luhur, memiliki pengetahuan dan keterampilan, kesehatan jasmani dan rohani, kepribadian yang mantap, dan mandiri serta bertanggungjawab. Berkembangnya nilai moral, spritual, dan keterampilan-keterampilan pada siswa tersebut menunjukkan bahwa sistem pada sekolah tersebut adalah sistem yang handal dan berkualitas.

Melihat posisinya yang sangat penting dalam suatu organisasi pendidikan,guru dan staf tata usaha dituntut untuk memenuhi standar profesional yang ditetapkan oleh pemerintah melalui perundang-undangan. Standar tersebut biasanya terkait dengan pendidikan minimal yang harus dimilikinya dan keterampilan-keterampilan yang terkait dengan proses pendidikan. Dengan 
standar tersebut diharapkan para guru mampu menjalankan tugasnya dengan baik sehingga target utama pendidikan yaitu terciptanya generasi yang handal berkualitas dapat tercapai.

Standar profesionalitas guru yang telah ditetapkan oleh pemerintah seringkali masih belum mampu menjawab berbagai persoalan di lapangan yaitu proses nyata pelaksanaan pendidikan di sekolah. Misalnya, secara administrasi guru telah memenuhi standar yang telah ditetapkan oleh pemerintah akan tetapi pada saat pelaksanaan tugas, mereka belum mampu menunjukkan bahwa dirinya adalah sosok yang profesional. Persoalan tersebut pada akhirnya akan memicu munculnya persoalan-persoalan terkait dengan motivasi dan kinerja. Keadaan tersebut tentu saja akan berpengaruh terhadap pendidikan, yakni menciptakan generasi yang handal dan berkualitas.

Mengingat bahwa cara pandang sangat berpengaruh terhadap motivasi kerja dan kinerja, penyelesaian persoalan sebagaimana telah diuraikan di atas adalah dengan mengubah cara pandang. Pengubahan cara pandang ini dimaksudkan agar guru memiliki kesadarankerja dan memandang suatu pekerjaan sebagai sebuah jalan hidup dan dapat menghidupinya. Dengan cara pandang ini, pekerjaan akan menjadi sesuatu yang lebih bermakna bagi mereka. Adanya kesadaran kerja tersebut akan menimbulkan sikap sukarela yang tinggi bagi guru dalam melaksanakan tugas-tugasnya. Hal ini pada akhirnya akan berdampak pada peningkatan motivasi kerja dan kinerjanya.

Sikap sukarela dan kesadaran dalam melaksanakan tugas-tugasnya, seringkali dikenal dengan istilah organizational citizenship behavior (OCB). Hal ini sejalan dengan pendapat Gibson, at al. (2009) dan Robin (2001) bahwa karyawan yang memiliki OCB tinggi dapat terlihat dari sikap mereka yang mau membantu rekan kerja, sukarela melakukan kegiatan ekstra di tempat kerja, menghindari konflik dengan rekan kerja, melindungi properti organisasi, menghargai peraturan yang berlaku di organisasi, toleransi pada situasi yang kurang menyenangkan di tempat kerja, memberi saran-saran yang membangun di tempat kerja, serta tidak membuang-buang waktu di tempat kerja.

Selain itu, sikap rela bekerja keras, suka membantu rekan kerja, menghindari konflik dan sebagainya, dapat juga disebut sebagai karakter. Hal ini sejalan dengan pendapat Wuryandani, dkk (2014) yang menyebutkan bahwa nilai-nilai karak- ter antara lain kejujuran, keterbukaan, toleransi, kebijaksanaan, disiplin diri, kemanfaat, saling menolong dan kasih sayang, keberanian dan nilainilai demokrasi. Dengan demikian pengembangan OCB pada setiap guru akan menumbuhkembangkan nilai-nilai karakter pada diri guru itu sendiri. karena hal ini menurut Pettalongi (2013) efektivitas pendidikan karakter akan terwujud jika ada sinergisitas dan keterpaduan antara keluarga, sekolah (guru) dan masyarakat.

OCB dan karakter merupakan manifestasi dari suatau keyakinan yang bersumber pada kesadaran (karakteristik) secara pribadi, maka usaha penumbuhkembangan OCB juga harus dimulai dari kesadaran pribadi. Oleh karena itu, penumbuhkembangan OCB dan karakter yang bersumber pada kepribadian dapat dilakukan melalui suatu keyakinan diri (yang bersifat pribadi) terhadap suatu nilai-nilai tertentu yang dianggap sebagai suatu kebenaran yang hakiki. Suatu nilai yang diyakini kebenarannya sebagai kebenaran yang mutlak adalah nilai-nilai yang bersumber pada keimanan seseorang. Oleh karena itu, sekolah sebagai suatu sistem pendidikan perlu menyelenggarakan pendidikan yang humanis. Pendidikan yang humanis menurut Pettalongi (2013) dapat memberikan pemaknaan yang mendalam terhadap basis keberagaman sebagai relaitas sosial. Salah satu realitas keberagaman tesebut adalah dalam hal keimanan atau keyanikan.

Nilai-nilai keimanan atau keyakinan seringkali dikenal dengan istilah nilai spiritual. Tingkat nilai keimanan atau nilai spiritual seseorang sangat bergantung pada kemampuan dirinya dalam mempelajari dan mengimplementasikan nilai-nilai tersebut dalam kehiduan sehari-hari. Kemampuan dalam mempelajari dan mengimplementasikan nilai-nilai keimanan/ spritual tersebut disebut dengan kecerdasan spiritual atau kecerdasaran rohaniah. Prijosaksono dan Erningpraja, (2003) menyebutkan bahwa kecerdasan spiritual berarti kemampuan manusia untuk dapat mengenal dan memahami dirinya (kesadaran diri) secara penuh sebagai makhluk spiritual maupun sebagai bagian dari alam semesta. Dengan memiliki kecerdasan spiritual yang tinggi berarti telah memahami sepenuhnya makna dan hakikat kehidupan yang dijalaninya.

Kesadaran diri berarti adalah kemampuan seseorang dalam mengatur, memosisikan atau mengatualisasikan dirinya dalam kehidupannya. Prijosaksono dan Erningpraja (2003) yang me- 
nyatakan bahwa spiritualitas adalah kebutuhan tertinggi manusia. Zohar dan Marshall (2001) menyebutkan bahwa spiritualitas merupakan kecerdasan puncak (ultimate intelligence). Spiritualitas adalah kecerdasan manusia yang paling tinggi melampaui dua kecerdasan yang dikenal sebelumnya, yaitu kecerdasan intelektual dan kecerdasan emosional yang telah populer sebelumnya. Karena kerohanian atau spiritualitas merupakan kebutuhan, hal ini berarti bahwa setiap manusia memiliki keinginan untuk memenuhi kebutuhan tersebut. Hal ini berarti pula bahwa setiap manusia memiliki potensi kesadaran diri yang tingkat kesdaran dirinya tersebut tergantung pada kecerdasaran spiritual (SQ) yang dimilikinya.

Spiritualitas adalah sebuah kebutuhan sebagaimana sebuah pekerjaan. Dengan demikian sebuah pekerjaan yang dikerjakan oleh para pekerja yang memiliki spiritualitas yang tinggi maka pekerjaan tersebut akan dapat dikerjakan dengan kualitas yang lebih baik dari pada dikerjakan oleh orang yang tidak memiliki nilai spiritualitas atau nilai spiritualitasnya rendah.Hal ini senada dengan pandangan Mohamed, at al. (2001), Srivastava dan Misra (2012) bahwa SQ memungkinkan manusia untuk melakukan halhal yang lebih kreatif, berwawasan luas, mampu membuat atau melanggar aturan-aturan terentu.

Terkait dengan hubungan nilai spiritualitas (SQ) dan pekerjaan, Dehler dan Welsh (1994) menjelaskan bahwa spiritualitas sebagai suatu bentuk spesifik perasaan dalam bekerja yang memberikan energi tindakan untuk melakukan sesuatu. Hawari (2006) juga menjelaskan bahwa salah satu faktor kesuksesan seseorang adalah adanya kecerdasan spiritual yang mereka miliki. Hal senada disampaikan oleh Muajiz (2009) bahwa kecerdasan spiritual dengan kecerdasan yang mengangkat fungsi jiwa sebagai perangkat internal diri yang memiliki kemampuan dan kepekaan dalam melihat makna yang ada dibalik kenyataan apa adanya. Agustian (2001) berpendapat bahwa kecerdasan spiritual adalah kemampuan untuk memberikan makna ibadah terhadap setiap perilaku dan kegiatan melalui langkah-langkah dan pemikiran yang bersifat fitrah, menuju manusia yang seutuhnya dan memiliki pemikiran tauhidi (integralistik).

Tumbuhnya nilai-nilai spiritual (SQ) se-seorang dapat dilihat dari tanda-tandanya dalam kehidupannya sehari-hari. Orang-orang yang memiliki SQ yang tinggi menurut Zohar dan Marshall (2001) akan terlihat dari adanya tanda-tanda berikut ini: (1) kemampuan bersikap fleksibel, (2) tingkat kesadaran diri tinggi, (3) kemampuan untuk menghadapi dan memanfaatkan penderitaan, (4) kemampuan untuk menghadapi dan melampaui rasa sakit, (5) kualitas hidup yang diilhami oleh visi dan nilai-nilai, (6) keengganan untuk menyebabkan kerugian yang tidak perlu, (7) kecenderungan untuk melihat keterkaitan antara berbagai hal (berpandangan holistik), (8) kecenderungan nyata untuk bertanya sekaligus mencari jawaban yang mendasar, (9) memiliki kemudahan untuk bekerja melawan konvensi.

Berdasarkan deskripsi di atas, terlihat dengan jelas bahwa nilai-nilai spritual (SQ) dapat diimplementasikan dalam suatu aktifitas atas pekerjaan dilakukan oleh seseorang dalam kehidupan kesehariannya. Beberapa penelitian yang terkait dengan hal itu antara lain di sampaikan oleh Hasan (2010) dan Pawar (2009) yang menyatakan bahwa keterlibatan spiritualitas di tempat kerja merupakan hal yang penting karena hal terebut memiliki kaitan yang sangat kuat dengan kehidupan manusia sebagai seorang individu, organisasi, dan masyarakat. Kolodinsky et al. (2007) dan Mohamed at al. (2001), menyatakan bahwa spiritualitas berdampak positif dengan keterlibatan kerja, identifikasi organisasional dan kepuasan reward kerja, dan berhubungan negatif dengan frustasi organisasional. Spiritualitas pribadi berhubungan positif dengan kepuasan instrinsik, ekstrinsik, dan keseluruhan kerja.

Berdasarkan uraian di atas, maka dapat dipahami bahwa OCB dan SQ merupakan dua variabel yang sangat penting dan saling memengaruhi dalam dunia kerja. Hal ini sebagaimana yang dinyatakan oleh Jayadi (2012) bahwa salah satu faktor yang mempengaruhi OCB guru adalah spiritual inteligent. Salah satunya adalah dunia kerja bidang pendidikan (di sekolah). Implementasi kedua variabel tersebut tentu saja selain meningkatkan kesadaran diri dalam bekerja, produktifitas kerja, motivasi kerja, kinerja juga akan berpengaruh terhadap kepuasan kerja. Oleh karena itu, kedua variabel di atas hendaknya mendapat perhatian yang lebih serius.

Pentingnya kedua variabel (OCB dan SQ) sebagaimana yang telah diuraikan di atas, belum sepenuhnya dipahami dan diimplementasikan di sekolah-sekolah. Bahkan masih banyak sekolahsekolah yang memisahkan antara prestasi kerja (OCB) dengan nilai spiritualitas para guru. Salah 
satu sekolah yang masih memisahkan antara variabel OCB dan SQ adalah MTs (Sekolah berbasis keagamaan)yang berada di kabupaten Saralangun, Propinsi Jambi. Sekolah tersebut termasuk salah satu sekolah yang besar dengan jumlah guru mencapai 56 orang, staf tata usaha 8 orang dan jumlah siswa sekitar 850 orang. Karena belum adanya pemahaman dan implementasi OCB dan SQ dalam proses pendidikannya, maka sekolah tersebut terkesan "kering" secara spiritualitas, "miskin" prestasi, tingkat kinerja guru dan staf tata usaha yang relatif masih rendah. Padahal menurut Pettalongi (2013) penanaman moral, nilai-nilai etika, estetika, budi perkerti luhur dan sebagainya merupakan hal yang lebih penting daripada aspek knowledge semata.

Salah satu cara yang dipandang dapat mengubah cara pandang dan menghasilkan kesadaran diri untuk berproduktifitas secara optimal maka diperlukan sebuah kegiatan pelatihan untuk guruguru tersebut. Hal ini sesuai dengan teori Becker sebagaimana dikutip oleh Sutarto (2013) bahwa pendidikan dan pelatihan akan meningkatkan penghasilan seseorang karena melalui pendidikan dan pelatihan seseorang dipremiskan akan meningkatkan kemampuan produktivitas yang pada gilirannya akan meningkatkan penghasilan. Oleh karena itu perlu dilakukan pelatihan peningkatan OCB dan SQ guru agar guru memiliki OCB dan CQ lebih baik sehingga produktivitasnya bertambah.

\section{METODE}

Penelitian ini menggunakan pendekatan kuasi ekspreimental, yaitu dilakukan dengan memberikan perlakukan (pelatihan) kepada responden. Keberhasilan perlakukan tersebut diukur dengan kemajuan atau peningkatan OCB dan SQ para peserta. Adapun peningkatan kedua variabel tersebut diukur dengan menggunakan nilai N-Gain yang dinormalisasi. Selain itu, kedua variabel tersebut juga dikorelasikan, untuk melihat sejauhmana kedua variabel saling memengaruhi subyek penelitian adalah guru yang mengajar di salah satu MTs Negeri di kabupaten Sarolangun, Provinsi Jambi. Jumlah subjek penelitian adalah 56 orang. Seluruh subjek tesebut ditempatkan pada sebuah aula sekolah untuk mengikuti program pelatihan berbasis spiritual yang dalam hal ini adalah berbasis nilai spriritual agama Islam.

Program pelatihan ini bertujuan menumbuhkembangkan kesadaran terhadap nilai-nilai yang terkadung dalam OCB dan karakter bedasarkan ajaran agama Islam. Di akhir pelatihan para peserta pelatihan diharapkan memiliki integritas, loyalitas dan rasa tanggung jawab yang berbingkai keikhlasan. Dengan terbagunnya sikap-sikap tersebut, produktivitas dan kreativitas dalam bekerja (mengajar dan mendidik) diharapkan dapat meningkat. Singkat kata, pelatihan ini dimaksudkan untuk mencitakan/menbentuk guru-guru MTs yang ber-OCB dan berkarakter tinggi sesuai dengan nilai-nilai dalam agama Islam.

Instruktur pelatihan adalah profesional yang diundang oleh sekolah dari suatu lembaga swasta. Pelatihan dilaksanakan selama 3 hari dengan durasi 8 jam. Materi disampaikan dalam berbagai metodologi (diskusi, permainan dan kuis, demonstrasi dan praktik, presentasi, berbagi cerita dan pengalaman, permainan peran, contoh-contoh kerumitan kerja dan pemecahan masalahnya) yang dilaksanakan secara indoor dan outdoor.

Sebelum pelaksanaan setiap responden diukur tingkat OCB dan SQ-nya (pretest) dengan instrumen yang telah dikembangkan sebelumnya dengan kualitas (validitas dan reliabilitas) instrumen didasarkan pada judgment expert dan penghitungan dengan menggunakan sofware ANATEST. Setelah akhir sesi setiap reponden diukur kembali tingkat OCB dan SQ (postest). Dengan demikian, data masing-masing variabel OCB dan SQ akan diperoleh dan diukur secara bersamaan. Selain itu, selama proses pelatihan berlangsung, seluruh responden diamati dengan teliti dan dicatat kejadian-kejadian yang terkait.

Teknik analisis data yang digunakan dalam penelitian ini adalah dilakukan dengan dua tahap. Tahap pertama untuk melihat sejauhmana peningkatan OCB dan SQ setiap responden. Peningkatan tersebut dianalisis dengan menggunakan $\mathrm{N}$-gain yang dinormalisasi, dengan rumus sebagai berikut:

Gain $=\frac{\text { Spost }- \text { S pre }}{\text { S max }- \text { S pre }} \times 100 \%$

Keterangan:

Spost $=$ skor tes akhir,

Spre $=$ skor tes awal, dan

Smax $=$ skor maksimum

Setelah perhitungan dengan persamaan tersebut dilakukan dan diperoleh nilai $\mathrm{N}$-gain maka proses selanjutnya adalah melakukan judg-' 
ment $\mathrm{N}$-gain seperti pada Tabel 1.

Tabel 1. Klasifikasi nilai N-gain

\begin{tabular}{lll}
\hline No. & Kategori Gain & Klasifikasi \\
\hline 1. & Gain $>70$ & Tinggi \\
2. & $30 \leq$ Gain $\leq 70$ & Sedang \\
3. & Gain $<30$ & Rendah \\
\hline
\end{tabular}

Untuk menguji korelasi antara OCB dan SQ akan dilakukan dengan korelasi product moment Spearman dengan bantuan software SPSS 20. Adapun hipotesis yang diuji dalam penelitian ini adalah:

\section{HASIL DAN PEMBAHASAN Model Pelatihan yang Dilaksanakan}

Pelatihan berbasis nilai spritual Islam disampaikan dalam berbagai multimetode. Hal ini dimaksudkan agar pelatihan tidak membosankan dan menjadi sebuah pelatihan yang bersifat interaktif dan tingkat partisipasi peserta tinggi. Tujuan pelatihan untuk mengembangkan sikap kesadaran diri dalam bekerja (OCB) dan berspiritual (SQ) tinggi. Dengan demikian, diharapkan muncul orang-orang yang memiliki OCB dan SQ yang baik.

Program pelatihan berbasis nilai spiritualIslam ini mengombinasikan urgensi OCB dalam bekerja dan nilai-nilai spiritual dalam pekerjaan sehingga dapat bekerja sesuai visi, misi, dan nilai-nilai moral dalam pendidikan secara holistik dengan performa kinerja terbaik. Dalam pelatihan berbasis nilai spritual Islam tersebut, responden diberikan motivasi, semangat, dorongan dan kemauan yang kuat dalam bekerja untuk mencapai tujuan, sasaran dan target yang telah ditetapkan. Hal ini dimaksudkan agar responden memiliki keyakinan, motivasi, semangat dan kemauan yang kuat untuk selalu tampil pada performa yang terbaik. Selain itu, pelatihan ini juga mengkondisikan agar rasa percaya diri responden meningkat, tumbuh minat yang kuat, antusiaisme yang tinggi serta mereka didorong untuk menetapkan target dan standar secara pribadiyang tinggi.

Observasi selama pelatihan berlangsung menunjukkan bahwa setiap peserta terlihat antusias, bersungguh-sungguh, bersemangat, muncul komitmen untuk memperbaiki diri. Selain itu, para peserta juga terlihat merasa bahagia saat menjalankan tugas dan tanggung jawabnya serta terlihat meningkatkan keyakinan (keimanan) dalam diri mereka. Secara kasat mata, program pelatihan tersebut membawa dampak positif bagi setiap peserta.

\section{Hasil Pelatihan Berbasis Spritual}

Hasil tes baik pretes maupun postessecara lengkap untuk seluruh responden ditunjukkan pada Tabel 2.

Berdasarkan Tabel 2. di atas, dapat disimpulkan bahwa program pelatihan berbasis nilai spiritual telah meningkatkan OCB dan SQ para guru.

\section{Korelasi antara OCB dan SQ}

Berdasarkan nilai N-gain yang diperoleh, terlihat korelasi keduanya sebagaimana yang ditunjukkan dalam Tabel 3.

\section{Tabel 3. Korelasi OCB dan SQ}

\section{Correlations}

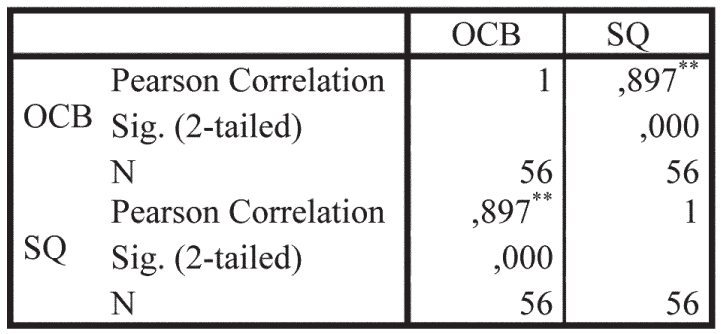

**. Correlation is significant at the 0.01 level (2-tailed).

Berdasarkan hasil analisis di atas, dapat dikatakan bahwa ada hubungan atau korelasi yang antara kedua variabel. Dengan demikian,

Tabel 2. Nilai Pretes, Postes dan N-gain Responden

\begin{tabular}{|c|c|c|c|c|c|c|c|}
\hline \multirow{2}{*}{ No. } & \multirow{2}{*}{ Kode Respondent } & \multicolumn{3}{|c|}{ Nilai OBC } & \multicolumn{3}{|c|}{ NILAI SQ } \\
\hline & & Pretes & Postes & N-Gain (\%) & Pretes & Postes & N-Gain(\%) \\
\hline 1. & SUM & 3849 & 4785 & & 3910 & 4839 & \\
\hline 2. & Rata-rata & 68,73 & 85,45 & 52,13 & 69,82 & 86,41 & 53,56 \\
\hline
\end{tabular}


semakin tinggi SQ seorang guru maka OCB-nya juga akan semakin meningkat dan demikian pula sebaliknya.

\section{Pembahasan}

Berdasarkan hasil uji terlihat bahwa OCB dan SQ responden mengalami peningkatan masing-masing 52,13\% dan 53,56\%. Kedua variabel tersebut meningkat lebih dari $50 \%$, hal itu berarti bahwa pelatihan berbasis spritual telah membawa dampak positif terhadap kedua variabel tersebut. Hal ini membuktikan bahwa program pelatihan berbasis nilai spiritual telah dilakukan merupakan pelatihan yang efektif dalam meningkatkan OCB dan SQ para guru.

Selama pelatihan berlangsung juga terlihat bahwa selama pelatihan berlangsung, para peserta terlihat memiliki semangat dan motivasi yang tinggi, bersungguh-sungguh dalam mengikuti pelatihan dan dalam melaksanakan setiap sesi pelatihan. Selain itu, peserta pelatihan terlihat adanya tanggung jawab yang tinggi dalam menjalankan tugas, memiliki keyakinan diri yang tinggi sehingga mereka merasakan adanya kebebasan dan keihklasan dalam bekerja. Hal tersebut membuktikan bahwa penyampaian materi dengan pola multimetode telah berjalan dengan baik sesuai target yang telah ditetapkan yakni meningkatkan OCB dan SQ para guru.

Adanya perubahan sikap para responden menunjukkan bahwa telah terjadi perubahan cara pandang dalam pikirannya terkait dengan pekerjaan dan keyakinan yang mereka miliki. Kemampuan dalam bersikap, bekerja, menghadapi tantangan serta kesadaran dan tanggung jawab yang tinggi dalam melaksanakan pekerjaan merupakan tanda bahwa seseorang tersebut memiliki OCB dan SQ yang tinggi. Hal ini sesuai dengan pendapat Zohar dan Marshall (2001) serta Robin (2001) yang menyatakan bahwa karyawan (guru) yang memiliki OCB dan SQ yang tinggi dapat terlihat dari sikap mereka diantaranya adalah sikap mau membantu rekan kerja, sukarela melakukan kegiatan ekstra di tempat kerja, menghindari konflik dengan rekan kerja, melindungi properti organisasi, menghargai peraturan yang berlaku di organisasi, toleransi pada situasi yang kurang ideal/ menyenangkan di tempat kerja, memberi saran-saran yang membangun di tempat kerja, serta tidak membuang-buang waktu di tempat kerja, memiliki kemampuan bersikap fleksibel, tingkat kesadaran diri tinggi, keengganan untuk menyebabkan kerugian yang tidak perlu, serta memiliki kemudahan untuk bekerja.

Perubahan sikap guru dan staf tata usaha sekolah sebagaimana telah diuraiakan di atas secara teori dapat mereduksi dan dapat menyelesaikan persoalan-persoalan yang dihadapi oleh sekolah tersebut selama ini. Beberapa persoalan tersebut misalnya masih banyak guru yang tidak mau memberikan pelajaran tambahan tanpa adanya honor, kerjasama antar guru yang masih rendah, guru kurang memiliki semangat, inovasi dan kreatifitas dalam melaksanakan tuganysa, masih banyak guru yang datang terlambat dan sebagainya.

Penyelesaian persoalan-persoalan tersebut terjadi karena dengan adanya peningkatan OCB dan SQ sebagai hasil dari pelatihan berbasis nilai spritual. Hal ini sejalan dengan pendapat Jayadi (2010) bahwa karyawan (guru) yang memiliki OCB tinggi di sekolah digambarkan dengan guru rajin memberikan pembelajaran, memanfaatkan waktu secara efesien, bekerja secara kolaboratif, serta lebih menekankan aktivitas-aktivitas profesional daripada kegiatan pribadi. Guru berusaha agar seluruh pihak yang terlibat di sekolah dapat diuntungkan, serta pendapat Kolodinsky et al. (2007) spiritualitas berdampak positif dengan keterlibatan kerja, identifikasi organisasional dan kepuasan reward kerja, dan berhubungan negatif dengan frustasi organisasional.

Selain itu, berdasarkan data data yang telah diperoleh dan analisis yang dilakukan sebagaimana yang telah diuraiakan di atas dapat dipahami bahwa OCB dan SQ memiliki korelasi atau hubungan yang sangat erat. Hal itu berarti antara kedua variabel tersebut dapat saling mempengaruhi. Semakin tinggi nilai spritual atau SQ seorang guru dan staf tata usaha makan akan semakin baik dan berkualitas pula pekerjaan (OCB) yang dilakukannya, demikian pula sebaliknya. Karena kedua variabel tersebut saling terkait erat, maka optimalisasi kedua variabel tersebut dapat dilakukan secara bersama-sama.

Saling keterkaitan antara OCB dan SQ membuktikan bahwa nilai-nilai spritualitas masih berpengaruh terhadap kualitas kerja seseorang. Hal ini sesuai dengan hasil penelitian Muajiz (2009) bahwa pelatihan, kecerdasan emosional dan spiritual memiliki pengaruh positif yang signifikan terhadap kinerja auditor. Demikian pula Jayadi (2012) yang mengatakan bahwa salah satu faktor yang mempengaruhi OCB guru adalah spiri- 
tual inteligent (SQ). Hal senada juga sampaikan oleh Hoffman (2002) yang mengatakan bahwa pekerja yang dapat memberi makna pada hidup dan membawa spiritualitas ke dalam lingkungan kerja akan membuat pekerja tersebut menjadi orang yang lebih baik, sehingga kinerja yang dihasilkan juga lebih baik dibanding pekerja yang bekerja tanpa memiliki kecerdasan spiritual

Berdasarkan uraian di atas, maka dapat ditegaskan bahwa pelatihan berbasis nilai-nilai spiritual dapat meningkatkan OCB dan SQ bagi para responden. Adanya peningkatan OCB dan SQ tersebut secara teori dapat mereduksi dan menyelesaikan berbagai persoalan yang dihadapi oleh guru dan staf tata usaha di sekolah serta berdampak positif terhadap kualitas kerja guru di sekolah tersebut. Dengan peningkatan OCB dan SQ guru tersebut maka secara tidak langsung akan meningkatkan proses pembelajaran yang bermuara pada kualitas keluaran/ lulusan, yang kemudia berakhir pada peningkatan kualitas pendidikan secara umum.

\section{SIMPULAN}

Berdasarkan kajian di atas, dapat diambil hal-hal sebagai berikut. Pertama, terjadi peningkatan OCB dan SQ pada pada seluruh responden setelah mengikuti program pelatihan berbasis nilai-nilai spritual dengan eningkatan masingmasing sebesar 52,13\% dan 53,56\%. Peningkatan tersebut berkategori "sedang". Kedua, peningkatan OCB dan SQ responden termasuk dalam kategori sedang. Ketiga, terdapat korelasi positif yang signifikan antara OCB dan SQ yang berarti semakin tinggi SQ seorang guru, maka OCB-nya juga akan semakin meningkat dan demikian pula sebaliknya.

\section{DAFTAR PUSTAKA}

Agustian, G. A. 2001. Rahasia Sukses Membangun Kecerdasan Emosi dan Spiritual (ESQ). Jakarta: Arga Wijaya Persada.

Dehler, Welsh, M. A. 1994. "Spirituality and Organizational Transformation: Implications for The New Management Paradigm". Dalam Journal of Managerial Psychology, 9, 17-26.

Gibson, Ivancevich, Donnely, Konopaske. 2009. Organization Behavior, Structure, Process. 3th edition, New York, Mc Graww Hill.
Hasan. 2010. "Spiritualitas dalam Perilaku Organisasi". Dalam Jurnal Dinamika Ekonomi \& Bisnis, Vol. 7 No. 1 Maret 2010.

Hawari, D. 2006. IQ, EQ, CQ, dan SQ: Kriteria sumber Daya Manusia Berkualitas. Jakarta: Gaya Baru.

Hoffman, E. 2002. Psychological Testing At Work. New York: McGraw-Hill.

Jayadi. 2012. "Kompetensi Guru, Spiritual Intelligence, Self Determination Theory dan Organization Citizenship Behavior". Dalam Jurnal Humanitas, Vol. IX No.2.

Kolodinsky, R.W. Giacalone, R.A. Jurkiewicz, C.L. 2008. "Workplace Values and Outcomes: Exploring Personal, Organizational, and Interactive Workplace Spirituality." Journal of Business Ethics, 81, 465-480.

Mohamed, Hassan, A. M. Wisnieski, J. M., 2001. Spirituality in the Workplace: A Literature Review. Global Competitiveness, 9, 644652.

Muajiz. 2009. Pengaruh Pelatihan, Kecerdasan Emosional dan Kecerdasan Spiritual Auditor terhadap Kinerja Auditor pada Direktorat Jenderal Pajak. Universitas Gadjah Mada, Jogjakarta.

Pawar, B. S. 2009. "Some of the Recent Organizational Behavior Concepts as Precursors to Workplace Spirituality". Dalam Journal of Business Ethics, 88, 245-261.

Pettalongi, Sagaf S. 2013. "Islam dan Pendidikan Humanis dalam Resolusi Konflik Sosial". Dalam Jurnal Cakrawala Pendidikan, Juni 2013, Th. XXXII, No. 2

Prijosaksono, A. dan Erningpraja, Irianti. 2003. Spiritualitas dan Kualitas Hidup.www.sinarharapan.com. Diunduh 7 Maret 2015.

Robbins, Stephen P. dan Judge, Timothy A. 2008. Perilaku Organisasi. Edisi 12. Jakarta: Salemba Empat. 
Srivastava, Abhilasha and Misra. 2012. "Is Spriritual Quotient A Beter Tool of Success: Spirituality in the New World Order". Dalam International Journal of Multidisciplinary Management Studies Vol.2 Issue 1, January 2012, ISSN 2249 8834. Online available at http://zenithresearch.org.in/.

Sutarto HP. 2013. "Strategi Penggeseran Paradigma Pelatihan dari Orientasi Aktivitas di Kelas ke Hasil di Tempat Kerja". Dalam Jurnal Cakrawala Pendidikan, Juni 2013, Th. XXXII, No. 2.
Wuryandani, Wuri, dkk. 2014. "Pendidikan Karakter Disiplin di Sekolah Dasar". Jurnal Cakrawala Pendidikan, Juni 2014, Th. XXXIII, No. 2.

Zohar, D., Marshall, I., 2001. Memanfaatkan Kecerdasan Spiritual dalam Berpikir Integralistik dan Holistik untuk Memaknai Kehidupan. Mizan, Bandung. 